\title{
Self-Healing Construction Materials: The Geomimetic Approach
}

\author{
Valery Lesovik ${ }^{1,2}$, Roman Fediuk ${ }^{3, *} \mathbb{D}$, Mugahed Amran ${ }^{4,5}$, Nikolai Vatin ${ }^{6}$ and Roman Timokhin $^{3}$ \\ 1 Department of Building Materials, Products and Structures, Belgorod State Technological University n.a. \\ V.G. Shukhov, 308012 Belgorod, Russia; naukavs@mail.ru \\ 2 Central Research and Design Institute of the Ministry of Construction, Housing and Utilities of the Russian \\ Federation, 119331 Moscow, Russia \\ 3 Polytechnic Institute, Far Eastern Federal University, 690922 Vladivostok, Russia; \\ timokhin.ra@students.dvfu.ru \\ 4 Department of Civil Engineering, College of Engineering, Prince Sattam Bin Abdulaziz University, \\ Alkharj 11942, Saudi Arabia; mugahed_amran@hotmail.com \\ 5 Department of Civil Engineering, Faculty of Engineering and IT, Amran University, Amran 9677, Yemen \\ 6 Peter the Great St. Petersburg Polytechnic University, 195251 St. Petersburg, Russia; vatin@mail.ru \\ * Correspondence: roman44@yandex.ru; Tel.: +79-502-817-945
}

Citation: Lesovik, V.; Fediuk, R.; Amran, M.; Vatin, N.; Timokhin, R. Self-Healing Construction Materials: The Geomimetic Approach. Sustainability 2021, 13, 9033. https://doi.org/10.3390/su13169033

Academic Editor: Yury Klochkov

Received: 8 July 2021

Accepted: 10 August 2021

Published: 12 August 2021

Publisher's Note: MDPI stays neutral with regard to jurisdictional claims in published maps and institutional affiliations.

Copyright: (c) 2021 by the authors. Licensee MDPI, Basel, Switzerland. This article is an open access article distributed under the terms and conditions of the Creative Commons Attribution (CC BY) license (https:/ / creativecommons.org/licenses/by/ $4.0 /)$.

\begin{abstract}
A person spends most of his life in rooms built from various building materials; therefore, the optimization of the human environment is an important and complex task that requires interdisciplinary approaches. Within the framework of the new theory of geomimetics in the building science of materials, the concepts of technogenic metasomatism, the affinity of microstructures, and the possibilities of creating composites that respond to operational loads and can self-heal defects have been created. The article aims to introduce the basic principles of the science of geomimetics in terms of the design and synthesis of building materials. The study's novelty lies in the concept of technogenic metasomatism and the affinity of microstructures developed by the authors. Novel technologies have been proposed to produce a wide range of composite binders (including waterproof and frost-resistant gypsum binders) using novel forms of source materials with high free internal energy. The affinity microstructures for anisotropic materials have been formulated, which involves the design of multilayered composites and the repair of compounds at three levels (nano-, micro-, macro-). The proposed theory of technogenic metasomatism in the building science of materials represents an evolutionary stage for composites that are categorized by their adaptation to evolving circumstances in the operation of buildings and structures. Materials for three-dimensional additive technologies in construction are proposed, and examples of these can be found in nature. Different ways of applying our concept for the design of building materials in future works are proposed.
\end{abstract}

Keywords: geomimetics; construction materials; affinity microstructures; technogenic metasomatism; $3 \mathrm{D}$ additive technology

\section{Introduction}

To analyze the present and future of any science, it is essential to build on a specific stage of the evolution of the Homo sapiens species and science in relation to overall global challenges facing society and problems affecting the coexistence of the organic and inorganic world as a whole [1-4]. Scientific progress occurs in parallel with the development of mankind [5-8]. Over time, discoveries have been made and inventions have been created that were relevant for a certain period in human evolution [9]. With the development of technology, some inventions of the past became completely unnecessary, and some entered our life forever [10]. At this stage of development, mankind has achieved certain successes, although these achievements could have been much greater if it had not been for a series of wars, natural and technological disasters, epidemics and other problems that, naturally, delayed the evolution and development of mankind [11-13]. At all stages of evolution, progress is determined by the development of science [14]. For two millennia, 
a path has been forged from philosophy and the fundamental sciences to applied research; society has passed from the Stone Age to industrial and post-industrial and the nature of human consumption has radically changed [15-18]. However, by the beginning of the XXI century serious problems arose, without the solutions of which it is difficult to count on long-term progress in the development of society (Figure 1) [19-24].

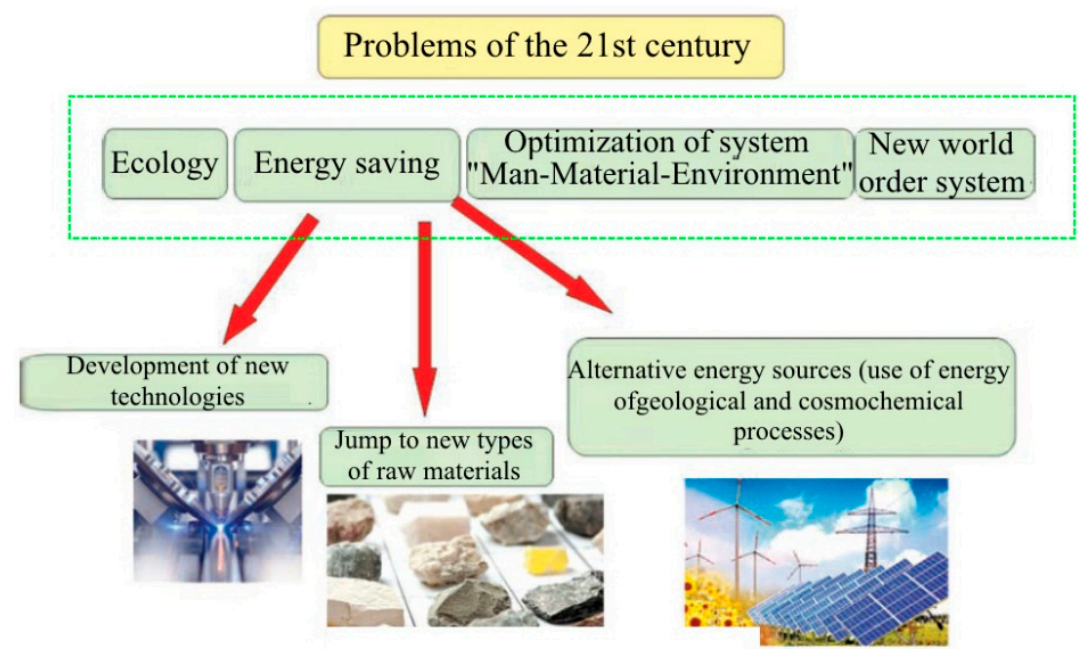

Figure 1. Directions for solving the problems of the 21st century.

Further development has been hampered by a lack of energy resources, environmental pressure on the human environment, etc., $[25,26]$. The main task of scientists from all over the world is to create a comfortable human environment from the standpoint of optimizing materials in relation to which a person spends most of his life [27-29]. This difficult task cannot be solved with a mono-and interdisciplinary approach. The study of the complex interaction of the components is possible only through transdisciplinary research [30-32]. Geomimetics is an approach to the creation of materials, composites, architectural ensembles, and works of art in which the ideas and technological schemes are borrowed from the study of geological and cosmo-chemical processes, minerals, rocks, and types of folding in order to create new composites for construction objects. Within the framework of the theoretical principles of geomimetics, a reduction in the energy intensity of the production of building materials is possible through the use of energy from geological and cosmo-chemical processes, and the use of energy-saving raw materials specially prepared by geological and cosmo-chemical processes [33-35]. The article aims to introduce the basic principles of the science of geomimetics in terms of the design and synthesis of building materials. The study's novelty lies in the concept of technogenic metasomatism and the affinity microstructures developed by the authors [36].

\section{Using a Novel Form of Source Material with High Free Internal Energy}

Novel technologies have been proposed to produce a wide range of composite binders (including waterproof and frost-resistant gypsum binders) using a novel form of source material with high free internal energy [37]. Such raw/source materials including clay rocks at the imperfect phase of the mineral development process and at the zone of sediment genesis, volcanic rocks with an amorphous and cryptocrystalline structure, and quartz-bearing rocks of the green shaled metamorphism stage are prospective, and are characterized by defects in the crystal lattice, including mineral-forming media, gas-air inclusions, and other features [38] (Figure 2). 


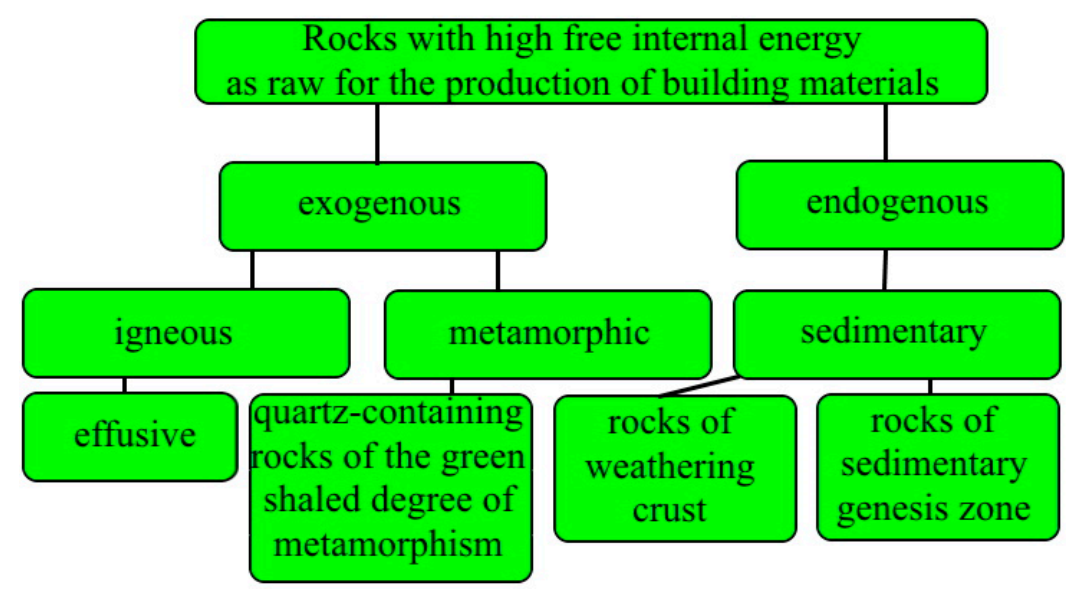

Figure 2. Classification of energy-saving raw materials in the construction industry.

The resulting building composites significantly exceed the traditionally produced performance characteristics with a clinker component saving of 50-70\% and are comfortable for the human environment [39]. Technology has been developed for producing wall materials with autoclave hardening through the use of clay rocks at an imperfect phase of mineral development with the possibility of reducing the time and pressure of autoclaving to 2-4 atm [40]. These rocks make it possible to control the structure formation processes of new generation autoclave materials [41]. At the same time, new growths of various compositions and morphology have been synthesized, forming cementing compounds of optimal composition, which ensures the high properties (physical and mechanical) of the products. Using raw/source materials from various fields and energy-saving technology, autoclave materials with an obtained compressive strength up to $40-45 \mathrm{MPa}$ have been produced [42]. A high dispersion of clay rocks allows the strength of the raw materials to be increased 2-4 times, facilitating the formation of high-hollow wall silicate materials with an average density of $1000-1300 \mathrm{~kg} / \mathrm{m}^{3}$ [43]. At the same time, energy costs are significantly reduced, and the number of raw materials used is reduced by $30-35 \%$ [44]. A wide range of effective autoclave materials based on this raw material, including wall, decoration, heat-insulating, structural and heat-insulating, and acoustic materials were researched by the authors of [45]. The use of these rocks will expand the raw material base of autoclave hardening materials, reduce the energy intensity of manufacture thereof, advance the ecological condition of the environment, and produce a comfortable standard of living for people [40].

The sustainability of the use of these new types of raw material lies in the fact that the energy consumption for the production of building materials is significantly reduced with the simultaneous utilization of what was previously considered waste.

\section{The Affinity Microstructures}

The affinity microstructures for anisotropic materials have been formulated, which involves the design of multilayered composites and the repair of composites at three levels (nano-, micro-, macro-) [46]. A new repair compound must be designed to be identical to the base matrix, which provides a way to significantly increase the bond strength and the physical and mechanical properties of materials [47]. The source of the formulation of this concept was the information obtained in the study of natural analogues of anisotropic and isotropic building composites [48] (Figure 3).

It was established that rocks, regardless of genesis (igneous, metamorphic, and sedimentary), have a banded texture, the layers of which are represented by minerals with significantly different deformation characteristics and coefficients of thermal expansion. These are not only short-lived, but they also have an anisotropy coefficient of 7-9 or more, unlike prototypes with an anisotropy coefficient of 2-3 [49]. An increase in the tensile strength of the masonry with the proposed compositions by $3-5$ times is elucidated by 
the microstructure of the region of contact, for instance, ceramic bricks and mortar [50] (Figure 4). The developed masonry mortar and the wall material are practically a single monolith; in the design of a traditional binder, the interfacial transition (contact) zone is clearly visible, which is the weakest point of the samples [51,52].

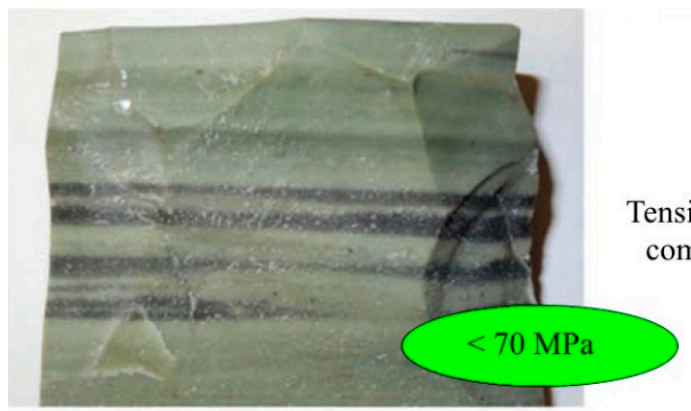

Banded rocks

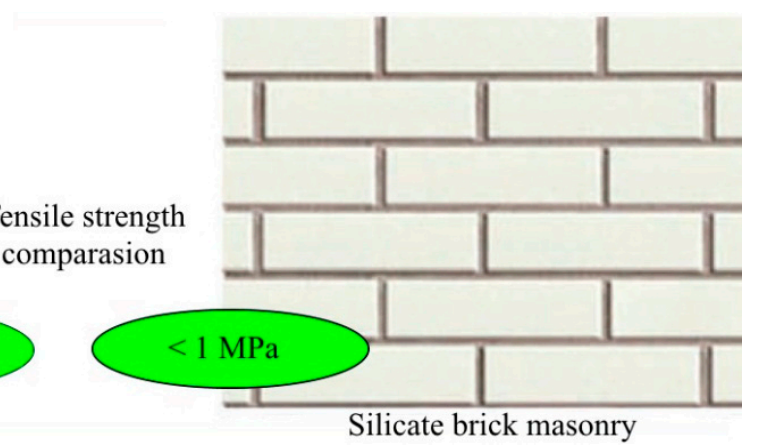

Figure 3. Different adhesion of similar materials (natural and ordinary artificial).
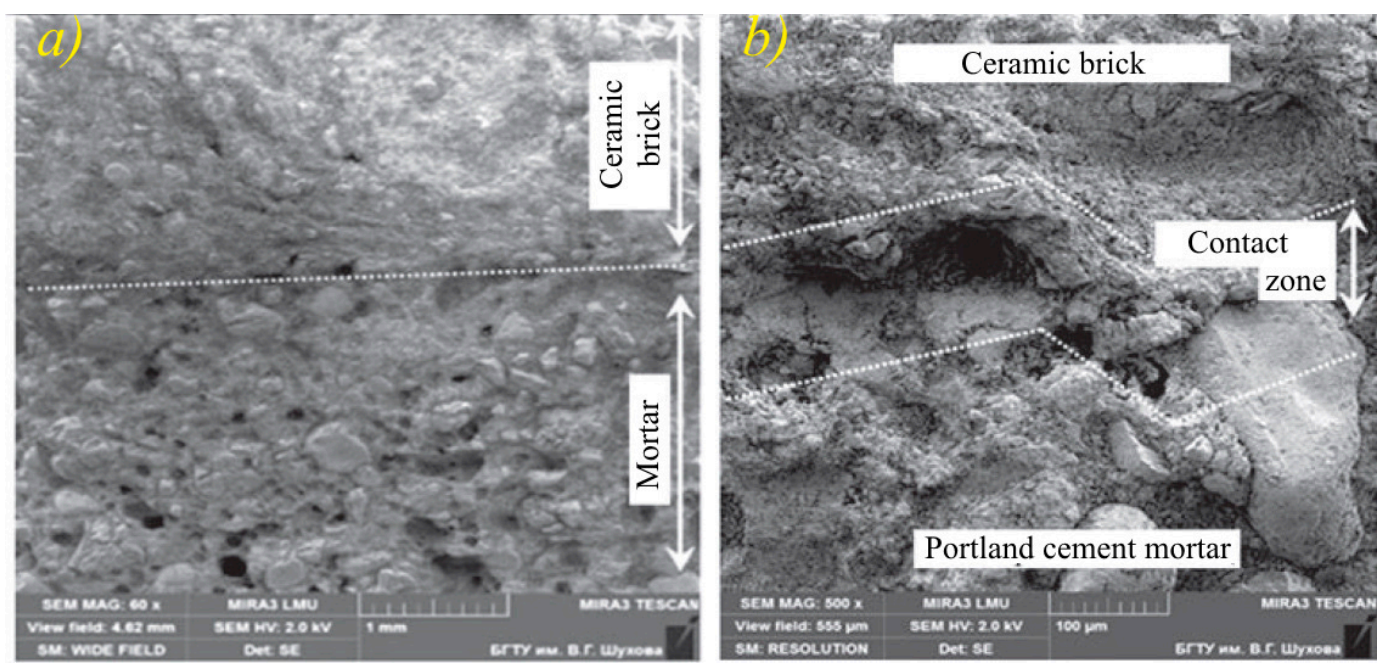

Figure 4. The effect of masonry mortar compositions on the structure of the contact zone: (a) masonry mortar, taking into account the affinity microstructures; (b) traditional masonry mortar.

The sustainability during the application of the affinity microstructures for repair compounds is related to the fact that the service life of buildings and structures is significantly increased, and building materials receive the potential for self-healing during the period of operation.

\section{The Technogenic Metasomatism}

Our proposed theory of technogenic metasomatism in building materials is a stage in the evolution of composites classified according to the degree of their adaptation to the changing operating conditions of buildings and structures [53]. One of the mechanisms of technogenic metasomatism is the contradiction between the composition and structure of the building composites' material and the new thermodynamic conditions they obtain during the construction and exploitation of buildings and structures. These complex processes (Figure 5) include recrystallization, diffusion, dehydration, crystallo-chemical transfiguration, transfiguration in the crystal lattices of a mineral, autogenesis (solid-phase recovery from a solution), etc., [54]. 


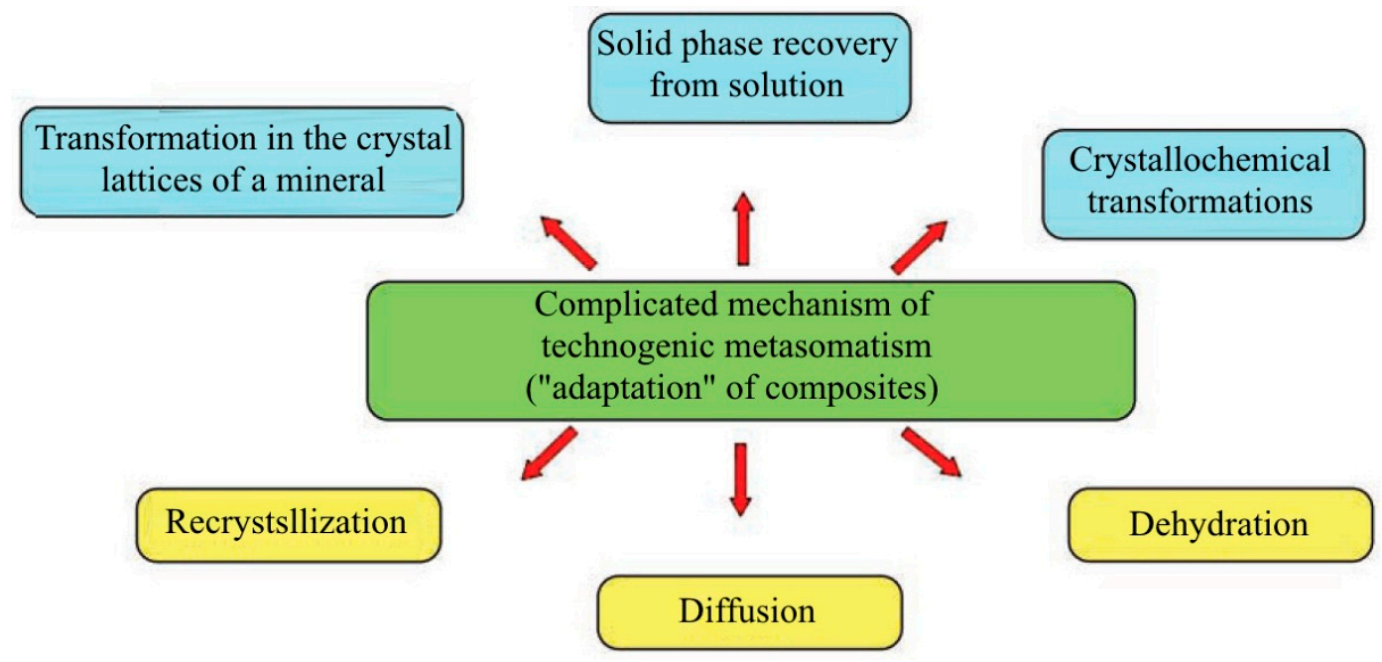

Figure 5. Processes of the technogenic metasomatism.

The design of composites, taking into account the theory of technogenic metasomatism in the building science of materials, allows for the possibility of the self-healing of defects that arise during the operation of buildings and structures and to obtain the so-called smart composites [55]. These are materials during the design of which an interaction with the environment is established, which allows them to respond to outside factors by self-healing the flaws that have appeared, positively affecting the man-material-environment triad. Our proposed method was investigated on composite binders using tuff, creating the most suitable environment at the initial stage of microstructure development, and hardening the hardening conglomerate. As a result, the hardened composite exhibits a decrease in stresses and a decline in the size and number of microcracks that regulates the cost effectiveness and technological use of composite binders based on tuff, especially in conditions of dry, hot weather. Volcanic tuff is called heteroporous rock. The void space of this breed is extremely difficult in shape and comprises an amalgamation of various sized pores (Figure 6).
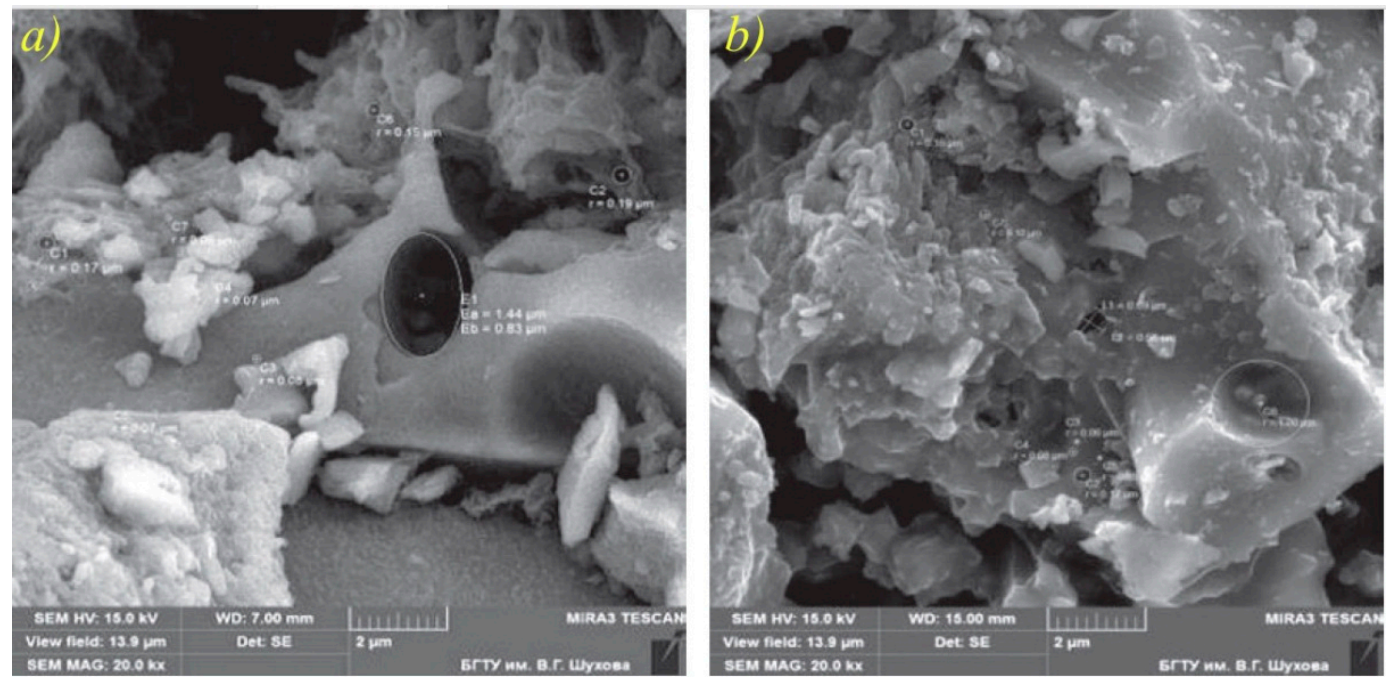

Figure 6. SEM images of the surface: (a) volcanic tuff; (b) tuff powder.

The water existence in the rock is in intricate interplay with its mineral skeleton, and the limitations and relationships between them are arbitrary and continually changing: the water can change into steam, chemically and physically bound water, and free or gravitational water. In hot weather, when there is a deficiency of the liquid phase in the composite itself, the tuff particles that make up the binder will give out the capillary- 
retained water stored by them during hardening, which leads to the activation of the operation of microstructure creation and the synthesis of a denser uniform microstructure of materials in the process of curing and the exploitation of concrete. Under the condition of service, microcracks arising under different loads self-destruct owing to the contact with the dampness present in tuff particles with nonreacted clinker minerals. During the service life, tuff particles give away the capillary-retained water stored by them, and this leads to the activation of structure development processes and the integration of a denser homogeneous materials/structure while hardening during the operation with concrete. This is how smart composites work. Given the theoretical principles of geomimetics, the great diversity of acoustic, heat-insulating, and structural-heat-insulating composites based on foam glass have been developed [56,57].

The sustainability of technogenic metasomatism lies in the fact that the material adjusts to changing temperatures and humidity conditions during the operation. As a result, the building material obtains a longer maintenance-free period and has a positive effect on human life indoors.

\section{The Three-Dimensional Additive Technology from the Perspective of Geomimetics}

Materials for three-dimensional additive technologies in construction are proposed and examples can be found in nature (Figure 7). Additive technology (layered synthesis technology) today is among the most prominent emerging areas in the field of science. In the relatively short span that has elapsed since the arrival of the three-dimensional printer, people now understand how to print dishes, dolls, vehicles, and even parts of the human body [58-60]. The extent of the objects that can be printed using a three-dimensional printer is continually growing. Work on the creation of the equipment for additive threedimensional technologies continues in many countries of the world, but there is currently no clear theoretical justification for the design and synthesis of building composites. Moreover, taking into account all the evolutionary transformations that are happening in the human environment, it is difficult to switch to the creation of three-dimensional skills in the construction complex. According to the analysis of the genetic features of the microstructure and composition of banded rocks, and their age and relationship to the weathering and destruction processes, proposals have been developed for creating composites for additive three-dimensional technologies in construction. The compositions of waterproof and frost-resistant gypsum binders have been created, the standard strength of which can be achieved in a short time $[61,62]$. It seems that it is precisely these composite binders that should become the basis for the development of additive three-dimensional technologies in construction [63].
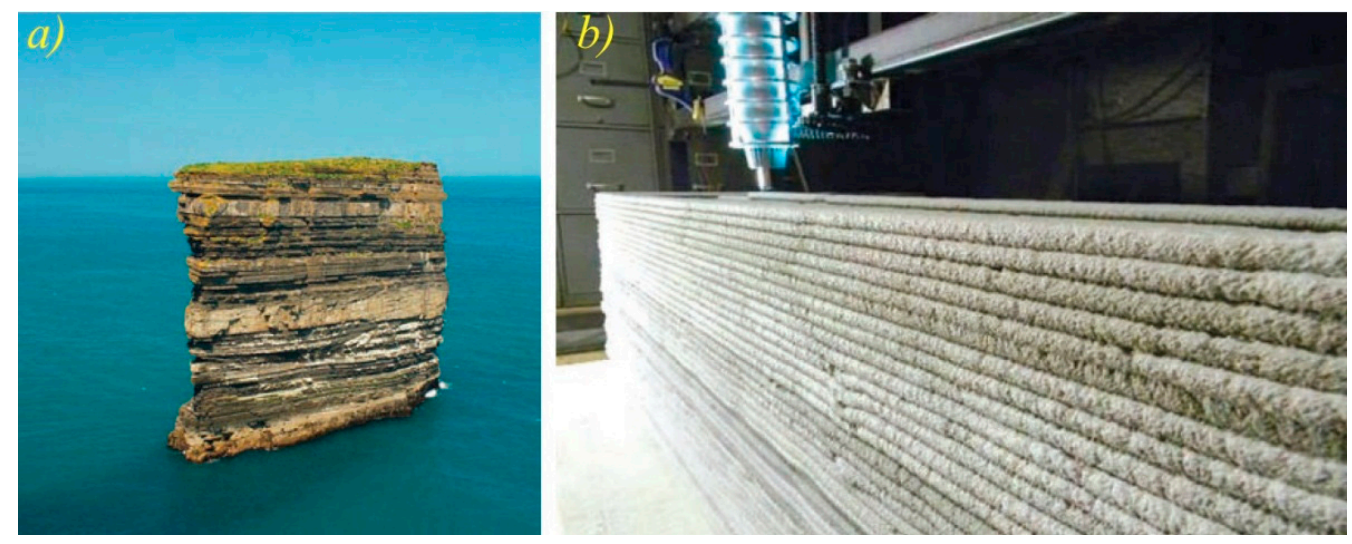

Figure 7. Additive technologies in nature (a) and in the construction industry (b).

The sustainability of additive technologies lies in the fact that a monolithic composite is created by a layer-by-layer synthesis. The increasing speed of construction allows a person 
to acquire great variability in the choice and comfort of the place of his permanent and temporary habitation.

\section{Challenges and Restrictions}

This paper provides examples of the implementation of geomimetics in building materials science. The prospects for further research in this direction relate to the assessment of the potential of substandard raw materials for the creation of building materials, including smart composites, that are capable of responding to the effects of various external factors. According to our forecasts, in the next 20 years, $90 \%$ of modern materials used in industry will be replaced by new ones, which will create structural elements that will determine the technological progress of the 21st century. The implementation of theoretical provisions and a systematic approach to solving the problems formulated through the framework of geomimetics make it possible to develop a methodological basis for the creation of effective building composites.

Based on this methodology, new effective wall materials with consistently high thermal insulation characteristics and an increased adhesion strength with masonry mortars for construction in earthquake-prone regions can be proposed for further research. Wall materials obtained using this technology will have a significantly more developed surface than traditional wall materials. Caverns formed in place of granules will significantly increase the strength of the masonry and taking into account the use of a specially developed masonry mortar, they can increase the shear strength of the masonry by 25-30 times, which is especially important for construction in earthquake-prone areas.

The second promising direction for further research is the development of self-healing systems, which will allow the creation of a more highly organized structure of cement paste at the macro-, micro-and nano-levels, and concrete as a whole at all stages, particularly at the stages of the mixing, hardening, and exploitation of the material. For this purpose, the use of volcanic tuffs is promising. These rocks have a heteroporous system due to nano-porosity and capillary and gel porosity. The binder obtained by the joint grinding of cement and tuff has a positive effect on the process of structure formation of concrete in hot climates and makes it possible to optimize traditional self-restoration concrete, which is used today in many countries of the world.

The third promising direction is the design of layered composites and repair systems at the nano, micro and macro levels similar to the base matrix, which will lead to a significant increase in the adhesion and durability of materials. Further development of masonry mortars, plaster mortars, and restoration mixtures is required.

The fourth promising direction is the development of highly efficient heat-insulating and structural glass composites of a new generation with protective and decorative properties and high heat-insulating, strength, and performance characteristics based on technogenic raw materials. The natural analogue of the material obtained is volcanic glass, which has high physical and mechanical properties. The creation of new highly efficient composites should be based on the principle of copying geological and cosmo-chemical processes in order to create new composites to optimize the human environment. This is required to clarify the regularities of the processes of structure formation and the development of principles for increasing the efficiency of non-autoclave aerated concrete through the use of composite binders, process control in a three-phase dispersed porous composite, and the improvement of technological methods for manufacturing aerated concrete products. Further research should be aimed at the formation of the composition and granulometry of binders, which correspond to the structure of thin interpore partitions, and the control of the properties of mixtures to combine the processes of gas formation and structure formation, taking into account the balance of forces in the initial mixture.

The fifth area for further research is the application of the provisions of geomimetics in additive technologies (layer-by-layer synthesis), which is one of the most dynamically developing areas in science. The fundamental basis for the design and creation of composites for additive technologies is the transition to transdisciplinary research, which is now 
prominent, including as a direction of geomimetics. Work on the creation of technology and equipment for three-dimensional additive technologies continues in many countries of the world, but there is currently no scientific justification for such building composites and technologies. Moreover, taking into account all the evolutionary transformations that are taking place in the human environment, it is not yet possible to switch to the creation of three-dimensional technologies in the construction complex.

\section{Conclusions}

This review manuscript summarizes the results carried out by the team of authors over the past 10 years in the framework of the transdisciplinary direction in building materials science (geomimetics). As a result, the following main conclusions were made:

1. The novel technologies have been proposed for the production of a wide range of composite binders (including waterproof and frost-resistant gypsum binders) using novel forms of source materials with high free internal energy. Such raw/source materials such as clay rocks at the imperfect phase of the mineral development process and at the zone of sedimentogenesis, volcanic rocks with an amorphous and cryptocrystalline structure, quartz-bearing rocks of the green shaled metamorphism stage are prospective, and are characterized by defects in the crystal lattice, including mineral-forming media, gas-air inclusions, and other features.

2. The affinity microstructures for anisotropic materials have been formulated, which involves the design of multilayered composite and the repair of compounds at three levels (nano-, micro-, macro-). This is identical to the base matrix, which provides a route to a substantial growth in the durability of the bond and materials. The source of the formulation of this concept was the information obtained in the study of natural analogues of anisotropic and isotropic building composites.

3. Our proposed theory of technogenic metasomatism in the building science of materials represents an evolutionary stage for composites that are categorized by their adaptation to evolving circumstances in the operation of buildings and structures. One of the mechanisms of technogenic metasomatism is the contradiction between the material composition and the structure of building composites and the new thermodynamic conditions which they obtain during the construction and exploitation of buildings and structures. These complex processes include recrystallization, diffusion, dehydration, crystallochemical transfiguration, transfiguration in the crystal lattices of a mineral, autogenesis (solid phase recovery from a solution), etc.

4. Materials for three-dimensional additive technologies in construction are proposed and examples can be found in nature. According to the analysis of the genetic features of the microstructure and composition of banded rocks and their age and relationship to the weathering and destruction processes, proposals have been developed for creating composites for additive three-dimensional technologies in construction. The compositions of waterproof and frost-resistant gypsum binders have been created, the standard strength of which can be achieved in a short time. It seems that it is precisely such composite binders that should become the basis for the development of additive three-dimensional technologies in construction.

Author Contributions: Conceptualization, V.L. and R.F.; methodology, M.A.; software, N.V.; validation, R.T., V.L. and R.F.; formal analysis, M.A.; investigation, N.V.; resources, R.T.; data curation, V.L.; writing-original draft preparation, V.L., R.F., M.A., N.V. and R.T.; visualization, V.L., R.F., M.A., N.V. and R.T.; supervision, V.L., R.F., M.A., N.V. and R.T.; project administration, V.L., R.F., M.A., N.V. and R.T.; funding acquisition, V.L., R.F., M.A., N.V. and R.T. All authors have read and agreed to the published version of the manuscript.

Funding: The research was funded by the Ministry of Science and Higher Education of the Russian Federation as the grant Self-Healing Construction Materials (contract No. 075-15-2021-590 dated 04.06.2021).

Conflicts of Interest: The authors declare no conflict of interest. 


\section{References}

1. Dong, W.; Lu, Y.; Wang, W.; Zong, L.; Zhu, Y.; Kang, Y.; Wang, A. A new route to fabricate high-efficient porous silicate adsorbents by simultaneous inorganic-organic functionalization of low-grade palygorskite clay for removal of Congo red. Microporous Mesoporous Mater. 2019, 277, 267-276. [CrossRef]

2. Han, H.; Rafiq, M.K.; Zhou, T.; Xu, R.; Mašek, O.; Li, X. A critical review of clay-based composites with enhanced adsorption performance for metal and organic pollutants. J. Hazard. Mater. 2019, 369, 780-796. [CrossRef] [PubMed]

3. Kumar, E.; Bhatnagar, A.; Hogland, W.; Marques, M.; Sillanpää, M. Interaction of inorganic anions with iron-mineral adsorbents in aqueous media-A review. Adv. Colloid Interface Sci. 2014, 203, 11-21. [CrossRef]

4. Justo-Reinoso, I.; Heath, A.; Gebhard, S.; Paine, K. Aerobic non-ureolytic bacteria-based self-healing cementitious composites: A comprehensive review. J. Build. Eng. 2021, 42, 102834. [CrossRef]

5. Kurpińska, M.; Ferenc, T. Experimental and numerical investigation of mechanical properties of light weight concretes (LWCs) with various aggregates. Materials 2020, 13, 3474. [CrossRef]

6. Lesovik, V.; Voronov, V.; Glagolev, E.; Fediuk, R.; Alaskhanov, A.; Amran, Y.H.M.; Murali, G.; Baranov, A. Improving the behaviors of foam concrete through the use of composite binder. J. Build. Eng. 2020, 31, 101414. [CrossRef]

7. Rucka, M.; Wojtczak, E.; Knak, M.; Kurpińska, M. Characterization of fracture process in polyolefin fibre-reinforced concrete using ultrasonic waves and digital image correlation. Constr. Build. Mater. 2021, 280, 122522. [CrossRef]

8. Chetty, K.; Xie, S.; Song, Y.; McCarthy, T.; Garbe, U.; Li, X.; Jiang, G. Self-healing bioconcrete based on non-axenic granules: A potential solution for concrete wastewater infrastructure. J. Water Process Eng. 2021, 42, 102139. [CrossRef]

9. Gebru, K.A.; Kidanemariam, T.G.; Gebretinsae, H.K. Bio-cement production using microbially induced calcite precipitation (MICP) method: A review. Chem. Eng. Sci. 2021, 238, 116610. [CrossRef]

10. Iqbal, D.M.; Wong, L.S.; Kong, S.Y. Bio-cementation in construction materials: A review. Materials 2021, 14, 2175. [CrossRef]

11. Fediuk, R. High-strength fibrous concrete of Russian Far East natural materials. In Proceedings of the IOP Conference Series: Materials Science and Engineering, Tomsk, Russia, 9-11 November 2015. [CrossRef]

12. Kurpińska, M.; Karwacki, J.; Maurin, A.; Kin, M. Measurements of thermal conductivity of LWC cement composites using simplified laboratory scale method. Materials 2021, 14, 1351. [CrossRef]

13. Fediuk, R.S.; Ibragimov, R.A.; Lesovik, V.S.; Pak, A.A.; Krylov, V.V.; Poleschuk, M.M.; Stoyushko, N.Y.; Gladkova, N.A. Processing equipment for grinding of building powders. In Proceedings of the IOP Conference Series: Materials Science and Engineering, Tomsk, Russia, 4-6 December 2017; Volume 327. [CrossRef]

14. Rajasekar, A.; Wilkinson, S.; Moy, C.K.S. MICP as a potential sustainable technique to treat or entrap contaminants in the natural environment: A review. Environ. Sci. Ecotechnol. 2021, 6, 100096. [CrossRef]

15. Rodríguez, D.; Busco, C.; Flores, R. Information technology within society's evolution. Technol. Soc. 2015, 40, 64-72. [CrossRef]

16. Casarejos, F.; da Rocha, J.F.V. Envisioning societal achievement and legacy of intergenerational yield vis-à-vis essential precepts for sustainability and stability of Earth's life-giving systems. Futures 2019, 105, 91-103. [CrossRef]

17. Lesovik, V.S.; Zagorodnyuk, L.K.; Babaev, Z.K.; Dzhumaniyazov, Z.B. Analysis of the Causes of Brickwork Efflorescence in the Aral Sea Region. Glas. Ceram. (English Transl. Steklo I Keramika) 2020, 77, 277-279. [CrossRef]

18. Almajed, A.; Lateef, M.A.; Moghal, A.A.B.; Lemboye, K. State-of-the-art review of the applicability and challenges of microbialinduced calcite precipitation (Micp) and enzyme-induced calcite precipitation (eicp) techniques for geotechnical and geoenvironmental applications. Crystals 2021, 11, 370. [CrossRef]

19. Salamanova, M.S.; Murtazaev, S.-A.Y.; Alaskhanov, A.K.; Ismailova, Z.K.; Salamanova, M.S. Development of Multicomponent Binders Using Fine Powders. 2019. Available online: https://www.researchgate.net/publication/335282059_Development_of_ Multicomponent_Binders_Using_Fine_Powders (accessed on 10 August 2021).

20. Ibragimov, R.A.; Korolev, E.V.; Deberdeev, T.R.; Leksin, V.V. Efficient complex activation of Portland cement through processing it in the vortex layer machine. Struct. Concr. 2019, 20, 851-859. [CrossRef]

21. Lukuttsova, N.; Ustinov, A. Concrete modified by additive based on biosilicated nanotubes. Int. J. Appl. Eng. Res. 2015, 10, 40457-40460.

22. Korsun, V.; Vatin, N.; Korsun, A.; Nemova, D. Physical-mechanical properties of the modified fine-grained concrete subjected to thermal effects up to $200{ }^{\circ} \mathrm{C}$. In Proceedings of the Applied Mechanics and Materials, Beijing, China, 12 October 2014.

23. Alfimova, N.; Pirieva, S.; Gudov, D.; Shurakov, I.; Korbut, E. Optimization of Receptural-Technological Parameters of Manufacture of Cellular Concrete Mixture. Constr. Mater. Prod. 2020, 1, 30-36. [CrossRef]

24. Yu, X.; Jiang, J.; Liu, J.; Li, W. Review on potential uses, cementing process, mechanism and syntheses of phosphate cementitious materials by the microbial mineralization method. Constr. Build. Mater. 2021, 273, 121113. [CrossRef]

25. Chen, X.; Charrier, M.; Srubar, W.V., III. Nanoscale Construction Biotechnology for Cementitious Materials: A Prospectus. Front. Mater. 2021, 7, 12-19. [CrossRef]

26. Wang, H.; Miao, L.; Sun, X.; Wu, L. Research Advances in Microbially Induced Carbonate. Hunan Daxue Xuebao J. Hunan Univ. Nat. Sci. 2021, 48, 70-81. [CrossRef]

27. Lesovik, V.S. The reducing effect of argon in the plasma treatment of high-melting nonmetallic materials (a review). Glas. Ceram. 2001, 58, 362-364.

28. Chernysheva, N.; Lesovik, V.; Fediuk, R.; Vatin, N. Improvement of Performances of the Gypsum-Cement Fiber Reinforced Composite (GCFRC). Materials 2020, 13, 3847. [CrossRef] [PubMed] 
29. Fediuk, R.; Mosaberpanah, M.A.; Lesovik, V. Development of fiber reinforced self-compacting concrete (FRSCC): Towards an efficient utilization of quaternary composite binders and fibers. Adv. Concr. Constr. 2020, 9, 387-395.

30. Fediuk, R.S.; Ibragimov, R.A.; Lesovik, V.S.; Akopian, A.K.; Teleshev, A.A.; Khankhabaev, L.R.; Ivanov, A.S. Application of cementitious composites in mechanical engineering. In Proceedings of the IOP Conference Series: Materials Science and Engineering, Tomsk, Russia, 4-6 December 2017; Volume 327. [CrossRef]

31. Elistratkin, M.Y.; Lesovik, V.S.; Zagorodnjuk, L.H.; Pospelova, E.A.; Shatalova, S.V. New point of view on materials development. In Proceedings of the IOP Conference Series: Materials Science and Engineering, Tomsk, Russia, 4-6 December 2017. [CrossRef]

32. Volodchenko, A.A.; Lesovik, V.S.; Cherepanova, I.A.; Volodchenko, A.N.; Zagorodnjuk, L.H.; Elistratkin, M.Y. Peculiarities of non-autoclaved lime wall materials production using clays. In Proceedings of the IOP Conference Series: Materials Science and Engineering, Tomsk, Russia, 4-6 December 2017.

33. Volodchenko, A.A.; Lesovik, V.S. Effective Composites Employing Fast-Hardening Gypsum Cement Binders for Additive Manufacturing. In Proceedings of the International Conference "Actual Issues of Mechanical Engineering" (AIME), Tomsk, Russia, 27 July 2017. [CrossRef]

34. Szelag, M. Evaluation of Cracking Patterns in Cement Composites-From Basics to Advances: A Review. Materials 2020, 13, 2490. [CrossRef] [PubMed]

35. Szelag, M. Properties of cracking patterns of multi-walled carbon nanotube-reinforced cement matrix. Materials 2019, 12, 2942. [CrossRef] [PubMed]

36. Szewczak, A.; Szelag, M. Physico-Mechanical and Rheological Properties of Epoxy Adhesives Modified by Microsilica and Sonication Process. Materials 2020, 13, 5310. [CrossRef]

37. Dinarvand, P.; Rashno, A. Review of the potential application of bacteria in self-healing and the improving properties of concrete/mortar. J. Sustain. Cem. Mater. 2021, 1, 1-34. [CrossRef]

38. Izotov, V.S.; Ibragimov, R.A. Hydration products of portland cement modified with a complex admixture. Inorg. Mater. 2015, 51, 187-190. [CrossRef]

39. Brasileiro, P.P.F.; Brandão, Y.B.; Sarubbo, L.A.; Benachour, M. Self-healing concrete: Background, development, and market prospects. Biointerface Res. Appl. Chem. 2021, 11, 14709-14725. [CrossRef]

40. Joshi, S.; Goyal, S.; Sudhakara Reddy, M. Influence of biogenic treatment in improving the durability properties of waste amended concrete: A review. Constr. Build. Mater. 2020, 263, 120170. [CrossRef]

41. Ortega-Villamagua, E.; Gudiño-Gomezjurado, M.; Palma-Cando, A. Microbiologically induced carbonate precipitation in the restoration and conservation of cultural heritage materials. Molecules 2020, 25, 5499. [CrossRef] [PubMed]

42. Nathaniel, O.; Sam, A.R.M.; Lim, N.H.A.S.; Adebisi, O.; Abdulkareem, M. Biogenic approach for concrete durability and sustainability using effective microorganisms: A review. Constr. Build. Mater. 2020, 261, 119664. [CrossRef]

43. Chuo, S.C.; Mohamed, S.F.; Setapar, S.H.M.; Ahmad, A.; Jawaid, M.; Wani, W.A.; Yaqoob, A.A.; Ibrahim, M.N.M. Insights into the current trends in the utilization of bacteria for microbially induced calcium carbonate precipitation. Materials 2020, 13, 4993. [CrossRef]

44. Griño, A.A.; Daly, M.; Klarissa, M.; Ongpeng, J.M.C. Bio-influenced self-healing mechanism in concrete and its testing: A review. Appl. Sci. 2020, 10, 5161. [CrossRef]

45. Lukuttsova, N. Water films (nanofilms) in cement concrete deformations. Int. J. Appl. Eng. Res. 2015, 10, 35120-35124.

46. Namsaraev, Z.B.; Melnikova, A.A.; Rudenko, A.P.; Komova, A.V. Processes of Nanosized Calcium Carbonate Formation by Microorganisms. Nanotechnol. Russ. 2020, 15, 20-27. [CrossRef]

47. Narasimha Bharadwaj Kumar, V.; Ramesh, B.; Amrithaganesan, S. Effect of the bacteria on the porosity and permeability on self healing concrete. J. Crit. Rev. 2020, 7, 1178-1187. [CrossRef]

48. Yu, T.; Souli, H.; Péchaud, Y.; Fleureau, J.-M. Optimizing protocols for microbial induced calcite precipitation (MICP) for soil improvement-a review. Eur. J. Environ. Civ. Eng. 2020, 1, 1-16. [CrossRef]

49. Barberán, A.; Chávez, D.; Cajas, A.; Egas, M.C.; Criollo, M.; Pineda, J.; País-Chanfrau, J.M.; Trujillo, L.E. A new area of application and research in bio-processes: Biotechnologies in civil construction. Rev. Bionatura 2020, 5, 1072-1077. [CrossRef]

50. Stanaszek-Tomal, E. Bacterial concrete as a sustainable building material? Sustainability 2020, 12, 696. [CrossRef]

51. Bogdanov, R.R.; Ibragimov, R.A. Process of hydration and structure formation of the modified self-compacting concrete. Mag. Civ. Eng. 2017, 73, 16-32. [CrossRef]

52. Radonjanin, V.; Malešev, M.; Marinković, S.; Al Malty, A.E.S. Green recycled aggregate concrete. Constr. Build. Mater. 2013, 7, 1503-1511. [CrossRef]

53. He, J.; Gray, K.; Norris, A.; Ewing, A.C.; Jurgerson, J.; Shi, X. Use of Biological Additives in Concrete Pavements: A Review of Opportunities and Challenges. J. Transp. Eng. Part B Pavements 2020, 146, 04020036. [CrossRef]

54. Xu, J.; Pan, J.; Cheng, F.; Wang, Y.; Jia, D.; Liu, Z. Research Progress of Concrete Microbial Self-healing Material. Kuei Suan Jen Hsueh Pao J. Chin. Ceram. Soc. 2021, 49, 429-440. [CrossRef]

55. Makul, N. Principles of Fiber-Reinforced Concrete. Struct. Integr. 2021, 18, 79-98.

56. Gubareva, E.N.; Ogurtsova, Y.N.; Strokova, V.V.; Labuzova, M.V. Comparative activity evaluation for silica raw materials and photocatalytic composite materials based on them. Obogashchenie Rud 2019. [CrossRef]

57. Loganina, V.I.; Skachkov, Y.P.; Ryzhov, A.D. Additive based on aluminosilicates for lime dry mortar mixes. In Proceedings of the IOP Conference Series: Materials Science and Engineering, Tomsk, Russia, 4-6 December 2017. 
58. Anastasiadou, C.; Vettese, S. "From souvenirs to 3D printed souvenirs". Exploring the capabilities of additive manufacturing technologies in (re)-framing tourist souvenirs. Tour. Manag. 2019, 71, 428-442. [CrossRef]

59. Javaid, M.; Haleem, A. Current status and applications of additive manufacturing in dentistry: A literature-based review. J. Oral Biol. Craniofacial Res. 2019, 9, 179-185. [CrossRef]

60. Singh, S.; Ramakrishna, S.; Singh, R. Material issues in additive manufacturing: A review. J. Manuf. Process. 2017, 25, 185-200. [CrossRef]

61. Klyuev, S.V.; Klyuev, A.V.; Khezhev, T.A.; Pukharenko, Y.V. High-strength fine-grained fiber concrete with combined reinforcement by fiber. J. Eng. Appl. Sci. 2018, 13, 6407-6412. [CrossRef]

62. Mathur, V.K. Composite materials from local resources. Constr. Build. Mater. 2006, 20, 470-477. [CrossRef]

63. Elistratkin, M.Y.; Kozhuhova, M. Analysis of the Factors of Increasing the Strength of the Non-Autoclave Aerated Concrete. Constr. Mater. Prod. 2020, 1, 59-68. [CrossRef] 